\title{
Analysis of the Effects of Relational Marketing Towards Tourist Satisfaction Level On Organizing a Tourism Event In South Sumatra Province
}

\author{
Pelliyezer Karo Karo \\ MICE and Event Management Study Programme \\ Palembang Polytechnic of Tourism \\ South Sumatera, Indonesia \\ pelliyezer@poltekpar-palembang.ac.idｈttps://orcid.org/0000-0002-2462-5297
}

\begin{abstract}
This study is to determine the effect of relational marketing on the level of tourist satisfaction with the organization of tourism events in South Sumatra Province. Relational marketing researched includes the variables of commitment, empathy, reciprocity, and trust. Data collection techniques used were interviews, questionnaires, and observations. The data analysis model used is multiple linear regression analysis with hypothesis testing carried out simultaneously and partially with the help of IBM SPSS Statistics 22 software. The study population was 925 foreign tourists who were or had participated in organizing tourism events in South Sumatra Province. Research on 174 samples shows the results that the independent variables consisting of commitment, empathy, reciprocity, and trust simultaneously have a very strong influence on the dependent variable level of tourist satisfaction. While partially, the study produced that there are two variables, namely empathy and trust which have a significant influence on the level of tourist satisfaction, where empathy is the most dominant variable.
\end{abstract}

Keywords-tourism events, relational marketing, customer satisfaction levels.

\section{INTRODUCTION}

One alternative approach that is currently starting to be widely used by companies or organizations is relational marketing, namely marketing principles that emphasize and try to attract and maintain good long-term relationships with customers, suppliers, and distributors. Relational marketing in marketing science is relatively new and research is rarely done, regarding this approach. The marketing strategy that has been widely used is transactional marketing where companies or organizations use more marketing which emphasizes direct marketing through catalogs, advertisements, direct sales, and others. In the 1980s a company or organization began using a relational marketing strategy.

Relational marketing is described by several researchers (Yau, et al., 1999) as a long-term bond between two parties. The bond can be a bond between the company and the customer. In the service industry, the relational marketing approach is suitable for use in its marketing strategy, this is by the nature of the service itself. Relational marketing itself can be done in various forms, one of which is using 4 (four) variables which include variables of commitment, empathy, reciprocity, and trust. Commitment is an effort made by a company or organization to create a commitment between the customer and the company or organization and efforts to build a close relationship with the customer.

Indonesian law number 10 of 2009, explains that tourism is a travel activity carried out by a person or group of people by visiting certain places for recreational purposes, personal development, or studying the uniqueness of the tourist attractions that are visited, in a temporary period (Ismayanti, 2010). Tourism is a variety of tourism activities and is supported by various facilities and services provided by the community, entrepreneurs, and government (Ismayanti, 2010). The law concerning Tourism, Tourism Attractions are all things that have a uniqueness, beauty, and value in the form of the diversity of natural wealth, culture, and man-made products that are the target or destination of tourist visits.

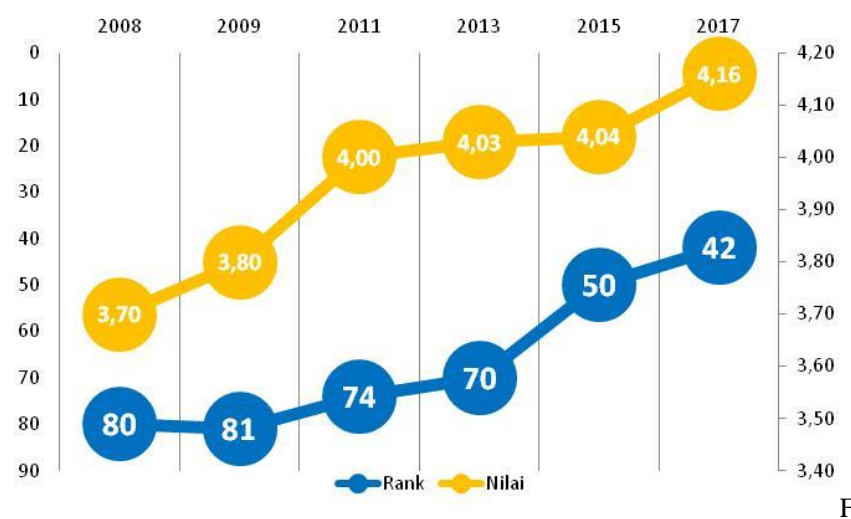

ig. 1. Performance of Indonesia's Competitiveness Index Year 2008-2017 Source: World Economic Forum (WEF) 2017

Based on data from the Indonesian Central Statistics Agency, the publication of Economic Indicators, January 2017 there was an increase in the ranking of tourism 
commodities towards the acquisition of Indonesia's foreign exchange since 2011 which was in the fifth position contributed to 8554.4 million US dollars and in 2016 rose to second position contributed amounted to $13,568.8$ million United States dollars in accordance with the Interim Tourism 2016 Foreign Exchange Calculation Data, Litbangjakpar, Ministry of Tourism. In developing Indonesian tourism in the eyes of the world, the government, in this case, the Ministry of Tourism penetrated the market through the country brand.

Strategy by promoting the Wonderful Indonesia tagline. Based on data from the World Economic Forum (WEF) 2017, among Asian countries, this branding strategy succeeded in bringing Indonesia to the 47th (forty-seven) position, ahead of Malaysia and Thailand. The results were also strengthened based on the 2017 Travel and Tourism Competitiveness Report, WEF, Indonesia's Tourism Competitiveness Index compared to ASEAN countries in 2017, succeeded in occupying the fourth rank after Singapore, Malaysia, and Thailand and continued to improve each year.

TABLE 1. COMPARISON OF ASIAN TOURISM FOREIGN EXCHANGE (MILLION USD)

\begin{tabular}{|c|l|c|c|c|c|c|}
\hline Peringkat & Negara & $\mathbf{2 0 1 1}$ & $\mathbf{2 0 1 2}$ & $\mathbf{2 0 1 3}$ & $\mathbf{2 0 1 4}$ & $\mathbf{2 0 1 5}$ \\
\hline $\mathbf{1}$ & Tiongkok & 48,464 & 50,028 & 51,664 & 105,380 & 114,109 \\
$\mathbf{2}$ & Thailand & $\mathbf{2 7 , 1 8 4}$ & $\mathbf{3 3 , 8 2 6}$ & $\mathbf{4 1 , 7 8 0}$ & $\mathbf{3 8 , 4 2 3}$ & $\mathbf{4 4 , 5 5 3}$ \\
\hline- & HongKong, SAR & 28,455 & 33,074 & 38,934 & 38,376 & 36,150 \\
$\mathbf{3}$ & Malaysia & $\mathbf{1 9 , 6 5 6}$ & $\mathbf{2 0 , 2 5 0}$ & $\mathbf{2 1 , 4 9 6}$ & $\mathbf{2 2 , 5 9 5}$ & $\mathbf{1 7 , 5 9 7}$ \\
$\mathbf{4}$ & Singapore & 18,086 & 18,939 & 19,209 & 19,134 & 16,743 \\
$\mathbf{5}$ & India & 17,707 & 17,971 & 18,397 & 19,700 & 21,013 \\
$\mathbf{6}$ & Japan & 10,966 & 14,576 & 15,131 & 18,853 & 24,983 \\
$\mathbf{7}$ & South Korea & 12,476 & 13,429 & 14,629 & 17,836 & 15,285 \\
$\mathbf{8}$ & Taiwan & $\mathbf{1 1 , 0 6 5}$ & 11,770 & 12,323 & 14,614 & 14,406 \\
$\mathbf{9}$ & Indonesia & $\mathbf{8 , 5 5 4}$ & $\mathbf{9 , 1 2 1}$ & $\mathbf{9 , 1 1 9}$ & $\mathbf{1 0 , 2 6 1}$ & $\mathbf{1 0 , 7 6 1}$ \\
\hline $\mathbf{1 0}$ & VietNam & 5,710 & $\mathbf{6 , 8 5 0}$ & $\mathbf{7 , 2 5 0}$ & 7,330 & 7,301 \\
\hline
\end{tabular}

Source: UNWTO Tourism Highlights, 2016 Edition

However, when referring to the UNWTO Tourism Highlights, 2016 Edition data, comparison of Asian tourism foreign exchange obtained the conclusion that Indonesia's tourism foreign exchange revenue is only half of Malaysia and a quarter of Thailand. Therefore, Indonesia is continuing to develop new tourist destinations called 10 (ten) priority tourism destinations (new Bali).

In addition to the ten new Bali destinations, the Government continues to branding other regions in Indonesia as a form of support for the Ministry of Tourism in meeting the target of 20 million foreign tourists in 2019. The Government of South Sumatra Province, for example, is prepared as one of the integrated sports event and sport tourism areas. The Provincial Government of South Sumatra, the capital of Palembang, is a land area of $87,421.24 \mathrm{~km} 2$, which is the host of the 2018 Asian Games. To support this existence, in addition to revitalizing attractions, organizing events is one of the important concepts in increasing tourism potential and attracting tourists. South Sumatra Province prepares 36 agendas of national and international tourism events held throughout
2018 which are held in districts/cities. In addition to the event, the city of Palembang as the provincial capital also held 32 event agendas in 2018.

Most of these events are dominated by cultural activities and sports, because by displaying cultural attractions will be a major attraction that has a unique value, exoticism, and scarcity or rarely even tourists are not found in the area of origin so that it can help tourists in planning a tour. While sports events are also on the main agenda because of the facilities and infrastructure in South Sumatra Province that meets the standards of implementing national and international sports activities. The whole agenda of the tourism event is poured into the event calendar and poured in two versions namely books and leaflets, and to facilitate the tourists to obtain this information, the Government of South Sumatra Province has prepared the delivery of all tourism information which can be accessed online on the southsumatratourism.com site.

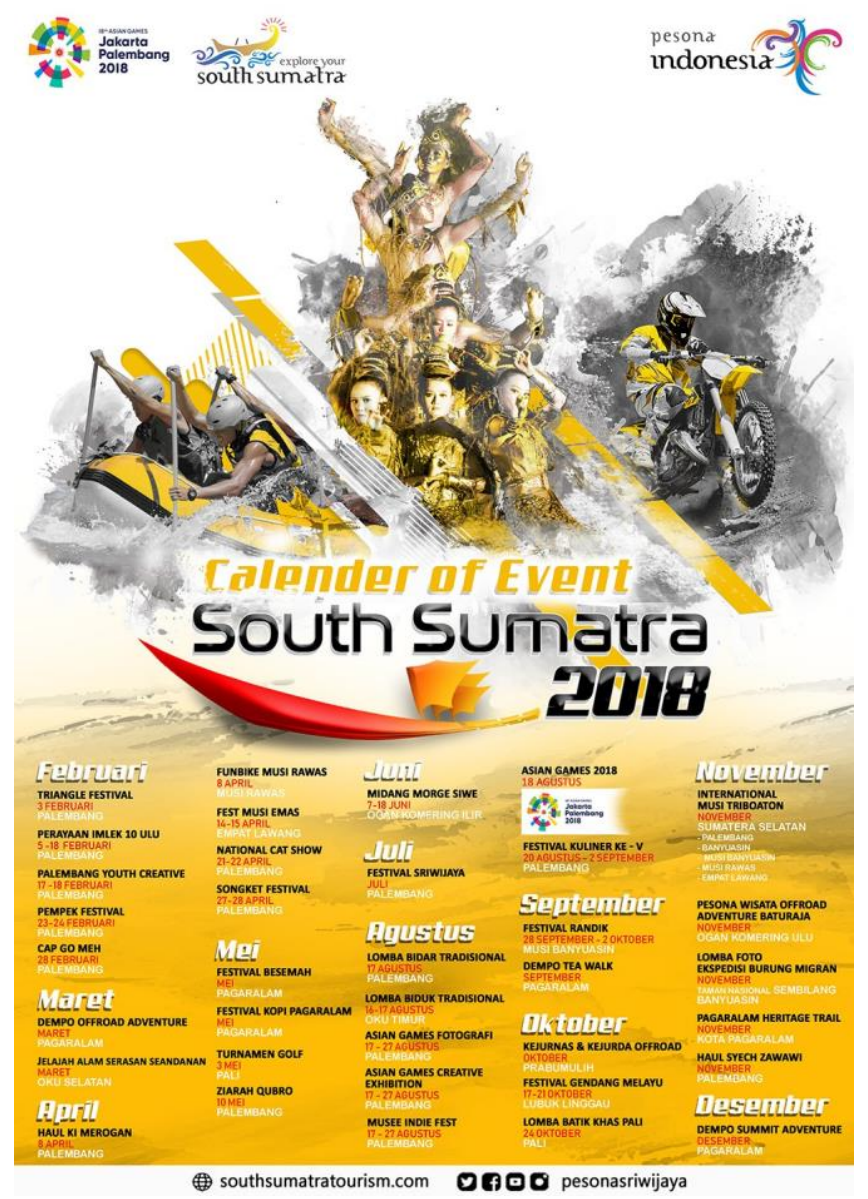

Fig. 2. 2018 Event Calendar, South Sumatra Province

Source: https://southsumatratourism.com/en/event-south-sumatra-2018/ 


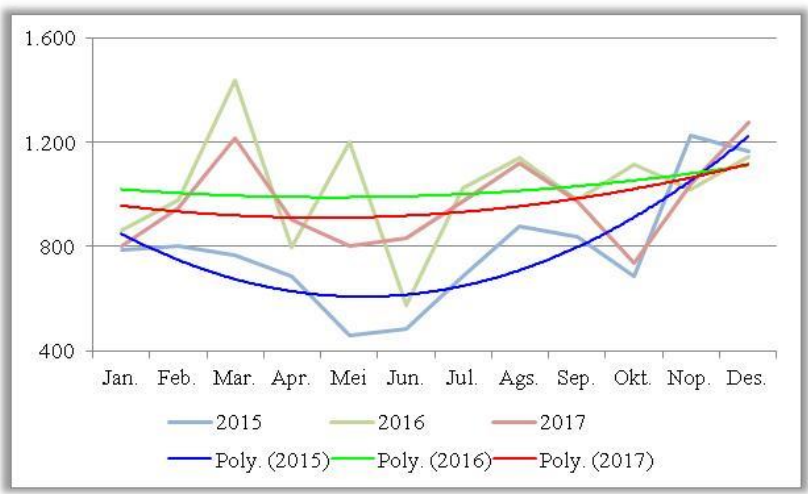

Fig. 3. Trend of International Tourist Visits, South Sumatra Province Source: 2018 Central Sumatra Province Statistics Agency, processed

The number of tourist visits to the Province of South Sumatra continues to change every year, in 2015 amounted to 9,441 people, 201612,276 people, 2017 amounted to 11,617 people, and as of September 2018, it has reached 9,970 people. When using the logarithmic trendline, foreign tourist arrivals in 2018 are estimated at 14,477 people, an increase of 24.62 percent from the previous year. Based on these data and visit trend graphs Figure 1.3. it can be seen that there is no specific pattern implemented in South Sumatra Province each year about increasing foreign tourist arrivals. The trend in 2015 is better than in 2016 and 2017. This has become one of the considerations of researchers in determining the South Sumatera Province as a research object.

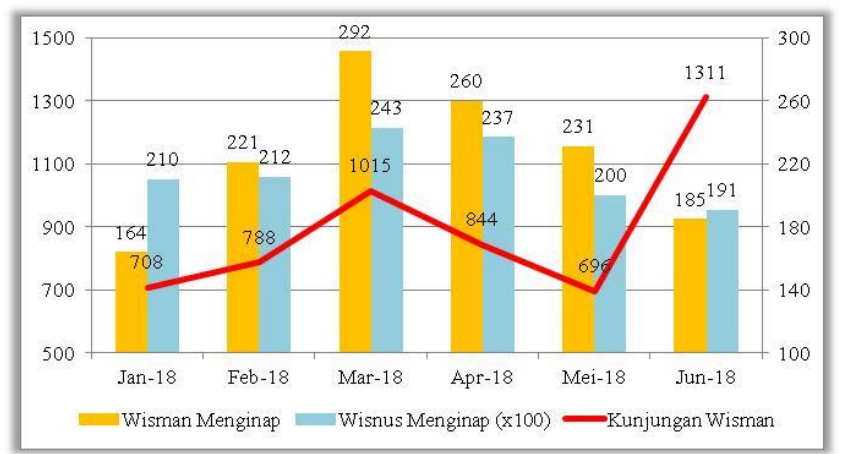

Fig. 4. Number of Foreign Tourist Visits and Room Occupancy Rate, South Sumatra Province

Source: 2018 Central Sumatra Province Statistics Agency, processed

In its development, the relational marketing method is a method that is quite effective in building growth and maintaining relationships with customers, in this case, are tourists both domestic and foreign. Increasing the accumulation of tourist arrivals each year in the Province of South Sumatra in general and the City of Palembang in particular, indirectly able to boost the achievement of national tourist visit targets, which can not be separated from the implementation of tourism events in the area. Researchers assume that relational marketing is one of the factors that must be considered in maintaining a positive visiting trend. Therefore it is necessary to have research to determine the level of customer satisfaction, by analyzing the influence of relational marketing on the level of tourist satisfaction in organizing tourism events in South Sumatra Province.

\section{LITERATURE REVIEW}

\section{A. Marketing}

Marketing is a very important part of the development of a company, because of the marketing activities are expected to generate profits to support the company's operations. This field deals directly with consumers so they must have the right strategies and work steps to get consumers as expected.

Kotler and Armstrong (2000) state that marketing is a social and managerial process carried out by individuals or groups in obtaining their needs and desires, by making and exchanging products and values with other parties.

To understand the notion of marketing, it is necessary to first understand the core concepts such as needs, wants and demands, products, values and satisfaction, exchanges, transactions and relationships, and the market. This understanding is necessary because these words have a special understanding of marketing needs. Figure 5. shows the relationship between these concepts.

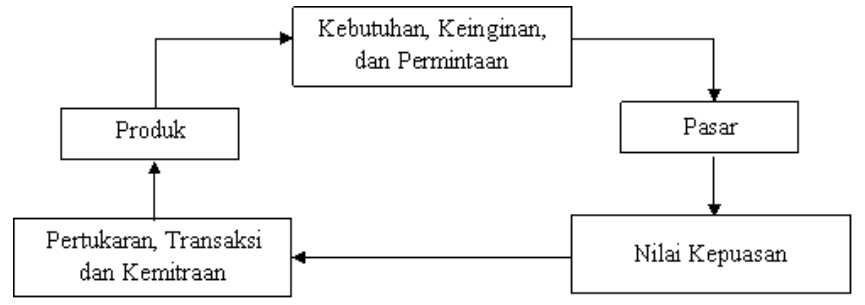

Fig. 5. Core Marketing Concepts

Source: Simamora (2001)

\section{B. Relational Marketing}

Relational marketing (relationship marketing) is very relevant to be discussed in service marketing, considering the involvement and interaction between customers and service providers is so high in most service businesses. A transactional marketing approach with high sales targets in the short term becomes less supportive of service business practices. Relational marketing emphasizes efforts to attract and retain customers by improving the company's relationship with its customers (Lupiyoadi, 2006). From the various definitions available, it can be concluded that relational marketing is:

1. Look for new values for customers and then producers and consumers share the created value.

2. Recognize the main role of individual customers not only as buyers, but also define the value they want. Here the value is created together with the customer.

3. The company needs to design and improve business processes, communication, technology and human resources in supporting the value desired by individual customers as a consequence of the business strategy and customer focus. 
4. Is a continuous cooperative effort between buyers and sellers.

5. Building a chain of relationships within the organization to create the desired customer value, and between the organization and its key stakeholders.

The main objective of relational marketing according to Zeithaml and Bitner (2003) is to build and maintain committed customers that are profitable for the company and at the same time minimize the time and effort spent on less profitable customers. While Chan (2003) states that the main purpose of relational marketing is actually to find the lifetime value (LTV) of the customer. After the LTV is obtained, the next goal is how to make the LTV of each customer group continue to be enlarged from year to year. After that, the next goal is how to use the profits from the first two goals to get new customers at a relatively low cost. Thus the long-term goal is to generate continuous profits from two groups of customers: current customers and new customers

In the research of Yau et al. (1999) stated that the current marketing philosophy shifted from transactional marketing to relational marketing, which is often referred to as Relationship Marketing Orientation. In that study, Yau et al. set four relational marketing variables that are used to measure company performance about the level of customer satisfaction. The four variables include commitment, empathy, reciprocity, and trust.

Commitment is a dimension of relational marketing that divides two parties, namely consumers and suppliers to act in an activity to achieve the desired goals (Callaghan in Yau et al., 1999). Commitment can be an effective social control in society, while at the same time contributing to eliminate doubts, create trust and form close relationships.

Empathy is a dimension of relational marketing that is used to look at situations from another perspective or perspective. This is interpreted by understanding the various desires and goals of others. This includes the ability of each individual to see the situation from another perspective in the cognitive sense (Hwang in Yau et al., 1999).

Reciprocity is a dimension of relational marketing that causes one party to reciprocate or return what has been obtained or commensurate with what it has received (Yau, et al., 1999). According to Tandjung (2004), reciprocity reflects that in long-term relationships one must give and take. That is, both the seller and the customer are equally profitable. And according to Sin et al. in Tjiptono (2005), reciprocity is a component of business relations that reflects the willingness of each party to help one another or reciprocate the kindness of one of the parties.

Trust can be interpreted as a party's confidence in another party or a relationship (relationship). In the context of relational marketing, trust is one of the dimensions of relational marketing to determine how far a party feels about the integrity and promises offered by other parties (Yau, et al., 1999).

\section{Customer Satisfaction}

Customer satisfaction is a very valuable thing to maintain customer presence. Of all the activities carried out by the company, in the end, it will lead to the value that will be given by the customer regarding the satisfaction he feels. According to Tjiptono (2006), there is not one single best measure of customer satisfaction that is universally agreed upon. However, amid various ways to measure the level of customer satisfaction, there are similarities in at least the six core concepts regarding measurement objects as follows:

1. Overall Customer Satisfaction

The simplest way to measure the level of customer satisfaction is to directly ask customers how satisfied they are with certain specific products or services. Usually, there are two parts to the measurement process. First, measure the level of customer satisfaction with the company's products or services concerned. Second, assess and compare it with the overall level of customer satisfaction with the products or services of competitors.

2. Dimensions of Customer Satisfaction

Various studies sort out the level of customer satisfaction into its components. Generally, this kind of process consists of four steps. First, identify key dimensions of customer satisfaction. Second, ask customers to rate the company's products or services based on specific items, such as service speed, service facilities, or customer service staff friendliness. Third, asking customers to rate competing products or services based on the same specific items, and Fourth, asking customers to determine the dimensions that they think are most important in assessing the overall level of customer satisfaction.

3. Confirmation of Expectations

In this concept, satisfaction is not measured directly but concluded based on the suitability/discrepancy between customer expectations with the actual performance of the company's products on several important attributes or dimensions.

4. Repurchase Intent Interest

Customer satisfaction is measured behaviorally by asking whether the customer will shop or use the company's services again.

5. Willingness to Recommend

In the case of products that are re-purchased for a relatively long time or even just a one-time purchase (such as a car purchase, home broker, life insurance, world tour, etc.), the customer's willingness to recommend the product to friends or family is an important measure to analyze and follow up. 
6. Customer Dissatisfaction

Several types of aspects that are often reviewed to determine customer dissatisfaction include a) complaints; b) product returns or returns; c) warranty costs; d) product recall (product recall from the market); e) negative transmission method; and $\mathrm{f}$ ) defections of consumers who turn to competitors.

With the existence of relational marketing carried out by the company, it is expected to create a level of customer satisfaction. The relationship between relational marketing and customer satisfaction is strengthened by the statement of Mudie and Cottam in Tjiptono (2006) that the level of total customer satisfaction is impossible even if only temporarily. However, efforts to improve and improve satisfaction can be done with a variety of strategies. This statement is reinforced by Rangkuti (2002), where the relationship between suppliers, producers, distributors, and customers (as of end users) is a vertical relationship that occurs in relational marketing. Relationships with customers will ultimately increase the level of customer satisfaction. Customer satisfaction includes the overall determination of the product or service that can create customer wants and needs. For this reason, it is very important for a company to create customer loyalty to a brand or service, and also provide benefits for the company.

\section{RESEARCH}

This type of research is observational with descriptive and analytic survey methods. Descriptive research in this study used survey data because the data used were collected by interview techniques supported by a schedule questionnaire or interview guide. Based on the data collected will be conducted research where this research is exploratory/explanatory. Descriptive research aims to detect the extent to which variations in one factor relate to other or more factors based on the correlation coefficient. The research approach used is a qualitative approach and a quantitative approach. The qualitative approach emphasizes the narrative or descriptive textual development of the phenomenon under study while quantitative research emphasizes numerical research on the phenomenon under study.

\section{A. Population and sample}

The population in this study are foreign tourists who are currently or have participated in the implementation of one particular event that is or has taken place in Palembang City, South Sumatra Province during the research process, with certain assumptions. Based on the publication of data from the Central Statistics Agency (BPS) of South Sumatra Province number 43/08/16 / Th.XX in August 2018, 1311 foreign tourists were visiting South Sumatra Province, with Occupancy Rate of Rooms (TPK) staying at a star hotel of 925 tourists, the details of the ROR for each star hotel are listed in Table 2. Based on the BPS publication in South Sumatra Province through 1102011.16 catalogs titled South
Sumatra Province in Figures 2018, it is known the number of hotels in each Regency / City, after processing, a ratio of $68.5 \%$ of accommodation is obtained located in the city of Palembang. This figure is used as a basis for determining the total population of the study of 634 foreign tourists.

\begin{tabular}{cccrr}
\multicolumn{5}{c}{ TABLE 2. OCCUPANCY RATES OF FOREIGN TOURIST ROOMS } \\
IN THE PROVINCE OF SOUTH SUMATRA, JUNE 2018
\end{tabular}

The sampling method used is to use probability sampling where each element of the population is allowed to be drawn into a sample member. The sampling technique used is simple random sampling, because the population to be studied is relatively homogeneous. Determination of the number of samples in this study using the Slovin formula. Thus the number of basic samples in this study were 245 tourists in the city of Palembang, by using a ratio between star hotels and population, a proportion of the sample size as respondents in each star hotel was obtained. In reality, from all the basic samples expected, in September to October 2018 there were $70.95 \%$ or 174 respondents who gave feedback with the results of the questionnaire that can be quantified later. This is caused by several limitations including location, communication technology, time and social factors of the respondents.

\section{B. Test Instruments}

The instrument validity and reliability test in this study were conducted on 30 respondents outside of the respondents used as research samples. The validity of research data is determined by an accurate measurement process. A measuring instrument is said to be valid if the instrument measures what should be measured. In other words, the instrument can measure the construct as expected by the researcher. Validity test is a measure that shows the level of reliability or validity of a measuring instrument.

By using the degree of freedom $(\mathrm{df})=28$ and the level of significance for the two-way test that is alpha $(\alpha)$ of 0.05 , the $r$ table value of 0.361 is obtained. Data processing to get the value of corrected item-total correlation is done using the help of the Statistical Package for Social Science (SPSS) version 22, the results show the calculated value of each question item. From the results of the instrument validity test, it shows that the calculated value of each question variable item $>r$ table value $(0.361)$, which means that each question variable item is declared valid or feasible to be used as a research questionnaire.

Reliability is a measuring tool concerning the degree of consistency and stability of data generated from the process of collecting data using these instruments. A questionnaire 
is said to be reliable or reliable if the respondent's answer to the question is consistent or stable over time. Respondents' answers to questions are said to be reliable if each question is answered consistently. Reliability testing is generally subject to testing instrument stability and internal instrument consistency.

In this research, reliability testing will be done using the one-shot method. The test tool that will be used for this test is the Cronbach Alpha Coefficient. The formula used to calculate the Cronbach Alpha Coefficient. From the instrument reliability test results, it shows that both the Cronbach alpha coefficient as a whole (0.877) and each instrument exceeds the minimum reliability limit used in this study, which is 0.7 . This indicates that overall all of the variable instruments in this study were reliable (consistent).

\section{Classical Assumption Test}

Normality test is performed to see whether the residual values generated from the regression model are normally distributed or not. A good regression model is one that has a residual value that is normally distributed. So the normality test is not carried out on each variable but the residual value.

The normality test can be done with the histogram test, the Pl plot P-value test, the Chi-Square test, Skewness and Kurtosis test or the Kolmogorov Smirnov test. In this study, the normality test will be carried out with the help of Statistical Package for Social Science (SPSS) version 22 software that uses the histogram facility and the Normal Probability Plot to determine residual normality from the regression model. Histogram or normal plot graph appears that the data or points spread around the graph or diagonal line and follow the direction of the graph or diagonal line, it can be stated that the regression model meets the assumption of normality.

Ghozali (2005) states that there are two ways to detect whether residuals are normally distributed or not, namely by graphical analysis and statistical tests. Therefore, to strengthen these results, in addition to graphical analysis researchers also use a statistical test that is the Kolmogorov Smirnov (K-S) test aimed at testing the normality of residual data, with an analysis in the form of:

1. Kolmogorov Smirnov's statistical test shows that the Zhitung value is 0.173 compared to the $\mathrm{Z}$ table value by selecting the level of significance $\alpha=0.05$ and the two-sided critical region in the standard normal distribution table is 0.567 . Because Zhitung is smaller than the $\mathrm{Z}$ table, residual data can be stated as normally distributed.

2. Asymptotic significance 2 tailed is a test of probability value to ensure that the observed distribution will not significantly deviate from the expected distribution at both ends of the two-tailed distribution. It is also known that this test is carried out by the lilliefors method, a method that uses basic data that has not been processed in the frequency distribution table. The data is transformed in the value of $\mathrm{Z}$ to be able to calculate the area of the normal curve as the normal cumulative probability. The probability has sought the difference with empirical commerce probability. The biggest difference compared to the lilliefors table in the normal distribution lilliefors statistical value table. The value of $\square \mathrm{F}$ (x) -S (x) was obtained at 0,000 compared to the value of the lilliefors table with $\alpha=0.05$ and $\mathrm{df}=174$ known at 0.067 . Because the value of $\square \mathrm{F}$ ( $\mathrm{x}$ ) $-\mathrm{S}$ ( $\mathrm{x}$ ) is smaller than the value of the lilliefors table, it can be stated that the residual data is normally distributed.

The multi-collinearity test is to see whether there is a high correlation between independent variables in a multiple linear regression model. If there is a high correlation between the independent variables, the relationship between the independent variables and the dependent variable is disturbed. According to Bhuono (2005), the detection of multicollinearity in the model can be seen from several things, including:

1. If the value of Variance Inflation Factor (VIF) is not more than 10 and the Tolerance value is not less than 0.1 , the model can be said to be free from multicollinearity. A low Tolerance value is the same as a high VIF value because of VIF $=1 /$ Tolerance.

Research results shows that the Tolerance value is not less than 0.10 which means there is no correlation between independent variables. The results of the calculation of the Variance Inflation Factor (VIF) value also showed the same thing that there was not one independent variable that had a VIF value of more than 10 . So it can be concluded that there was no multicollinearity between the independent variables in the regression model in this study.

2. If the coefficient value between each independent variable is less than 0.70 then the model can be said to be free from the classic assumption of multicollinearity. If more than 0.7 then it is assumed that there is a very strong correlation between independent variables so that multicollinearity occurs.

Research results shows that between independent variables have a correlation value of less than 0.70 which means there is no correlation between independent variables. So it can be concluded that there is no multicollinearity between independent variables in the regression model in this study.

The heteroscedasticity test aims to test whether in the regression model there is an inequality of variance from the residuals of one observation to another. If the variance from one observation residual to another observation is fixed, then it is called homoscedasticity and if different is called heteroscedasticity. Detection of heteroscedasticity 
symptoms can be tested using the Glejser test, namely by regressing the absolute residual value of the independent variable (Ghozali, 2005). Heteroscedasticity with the Glejser test does not occur if none of the independent variables is statistically significant affecting the dependent variable absolute value Ut (AbsUt).

Based on research results shows that none of the independent variables that are statistically significant affect the dependent variable Absolute Ut (AbsUt). This can be seen from the probability of significance (Sig.) above the 5 percent confidence level. So it can be concluded that the regression model in this study did not occur with heteroscedasticity.

\section{DATA ANALYSIS}

\section{A. Descriptive Analysis}

In this study, respondents were divided into six characteristics, namely based on age, gender, occupation, country of origin and length of stay, which can be obtained

\begin{tabular}{|c|c|c|c|c|c|}
\hline Model & $\begin{array}{l}\text { Sum of } \\
\text { Squares }\end{array}$ & df & $\begin{array}{l}\text { Mean } \\
\text { Square }\end{array}$ & $F$ & Sig. \\
\hline 1 Regression & 259,841 & 4 & 64,960 & 224,212 &, $000^{b}$ \\
\hline Residual & 48,964 & 169 & 290 & & \\
\hline Total & 308,805 & 173 & & & \\
\hline
\end{tabular}

a. Dependent Variable: Kepuasan_Pelanggan

b. Predictors: (Constant), Kepercayaan, Komitmen, Timbal_Balik, Empati

by some basic conclusions from the respondents namely:

1. The respondent's age interval is 27-57 years, with an average age of 40-41 years.

2. Respondents are dominated by male tourists.

3. The private sector is the dominance of the work of tourists.

4. Tourists are predominantly from Malaysia.

5. Most tourists spend 3-4 days stay.

\section{B. Analysis of Multiple Linear Regression}

In connection with this research is to examine the extent of a dependent variable, in this case customer satisfaction is influenced by several independent variables, in this case, 4 (four) relational marketing factors consisting of Commitment, Empathy, Reciprocity, and Trust, then the analysis model that will be used to study this relationship is the multiple linear regression analysis models. In the multiple linear regression analysis a regression equation will be developed, which is a formula that looks for the value of the dependent variable from the known independent variable values, namely:

$$
\mathrm{Y}=\mathrm{a}+\mathrm{b}_{1} \mathrm{X}_{1}+\mathrm{b}_{2} \mathrm{X}_{2}+\mathrm{b}_{3} \mathrm{X}_{3}+\mathrm{b}_{4} \mathrm{X}_{4}+\mathrm{e}
$$

Where:

$\mathrm{Y}=$ Customer Satisfaction

$\mathrm{X} 1=$ Commitment
$\mathrm{X} 2=$ Empathy

$\mathrm{X} 3=$ Reciprocal

$\mathrm{X} 4=$ Trust

e $=$ epsilon or variables not examined

Multiple linear regression analysis aims to find out how much influence the independent variable causes the dependent variable. Analysis of the research data was carried out at a confidence level of 95 percent with an error tolerance level (alpha) of 5 percent.

To test the effect of relational marketing which consists of commitment, empathy, reciprocity, and trust simultaneously on the level of tourist satisfaction in South Sumatra Province, the Statistical F test (F test) is used. If the value of F-count $>$ F-table value, then $\mathrm{Ho}$ is rejected and $\mathrm{Ha}$ is accepted. Conversely, if the value of F-count $<$ F-table value, then Ho is accepted and $\mathrm{Ha}$ is rejected.

Based on Table 7. the following will show that the value of F-count is 224.212 and the significance level is 0.000 while using a confidence level of 95 percent or $\alpha=$ 0.05 , df $1=3$, df2 $=169$ the F-table value of 2.66 is obtained. By comparing the values of F-count and F-table, it is known that F-count (224.212) > F-table (2.66) and Sig. $(0,000)<\alpha(0.05)$, meaning that Ho is rejected, and $\mathrm{Ha}$ is accepted, which means simultaneously the relational marketing variable consisting of commitment, empathy, reciprocity, and trust has a positive and very significant effect on the level of satisfaction tourists in South Sumatra Province.

TABle 3. SimultaneOUS SignificANT TEST (STATISTICAL TEST F) Source: Research Results, 2018 (IBM SPSS Statistics 22, processed)

To test the effect of relational marketing consisting of commitment, empathy, reciprocity and partial trust in the level of tourist satisfaction in South Sumatra Province, the ttest was used. If $\mathrm{t}$-count $>\mathrm{t}$-table, then Ho is rejected and $\mathrm{Ha}$ is accepted. Conversely, if the value of t-count $<\mathrm{t}$-table, then Ho is accepted and $\mathrm{Ha}$ is rejected.

TABLE 4. TEST THE SIGNIFICANCE OF INDIVIDUAL PARAMETERS (STATISTICAL TEST T)

\section{Coefficients $^{\mathrm{a}}$}

\begin{tabular}{|c|c|c|c|c|c|}
\hline Model & $\begin{array}{l}\text { Unstan } \\
\text { Coeffici } \\
\text { B }\end{array}$ & $\begin{array}{l}\text { dardized } \\
\text { ents } \\
\begin{array}{l}\text { Std. } \\
\text { Error }\end{array}\end{array}$ & \begin{tabular}{|l}
$\begin{array}{l}\text { Stand. } \\
\text { Coef. }\end{array}$ \\
Beta \\
\end{tabular} & & Sig. \\
\hline $1 \quad$ (Constant) & 293 & ,336 & & 870 & 386 \\
\hline Komitmen & 021 & ,027 & ,026 & ,779 & 437 \\
\hline Empati & 731 & ,040 & 799 & 18,459 & ,000 \\
\hline Timbal_Balik & , 041 & ,032 & ,051 & 1,290 & 199 \\
\hline Kepercayaan & 151 & 034 & 161 & 4,414 & 000 \\
\hline
\end{tabular}

a. Dependent Variable: Kepuasan_Pelanggan

Source: Research Results, 2015 (IBM SPSS Statistics 22 and processed)

Based on Table 8. obtained a linear regression equation model in this study, namely:

$$
Y=0.293+0.021 X_{1}+0.731 X_{2}+0.041 X_{3}+0.151 X_{4}
$$


Meaning:

1. Based on the above equation, if $\mathrm{X} 1, \mathrm{X} 2, \mathrm{X} 3, \mathrm{X} 4=$ 0 , then the $Y$ value is 0.293 . This means that if the level of customer satisfaction is not influenced by the four variables of commitment, empathy, reciprocity, and trust, then the level of customer satisfaction is 0.293 units.

2. A constant value of 0.163 can mean that the average contribution of other variables outside the model has a positive impact on the level of customer satisfaction.

3. Based on the above equation, it shows that if $\mathrm{X} 1$, $\mathrm{X} 2, \mathrm{X} 3, \mathrm{X} 4$ are added by one unit, the level of customer satisfaction will increase by $0.021 \mathrm{X} 1$; $0.731 \mathrm{X} 2 ; 0.041 \mathrm{X} 3$ and $0.151 \mathrm{X} 4$ units.

Based on Table 8. also shows the t-value of each independent variable in this study, which will be compared with the t-table value using a confidence level of 95 percent or $\alpha=0.05$ and $\mathrm{df}=169$, then the t-table value of 1.653 is obtained.

The results of partial hypothesis testing indicate that the commitment variable $\left(\mathrm{X}_{1}\right)$ has:

1. T-count value of 0.779 is smaller than the table value which means the commitment variable does not affect the level of customer satisfaction.

2. The significance value of 0.437 is greater than the value of $\alpha$ which means the commitment variable is not significant to the level of customer satisfaction, where if the commitment variable is increased by one unit, the level of customer satisfaction will increase by 0.021 units.

This means that the decision is that Hol is accepted and Hal is rejected, meaning that partially the commitment variable does not significantly influence the level of tourist satisfaction in South Sumatra Province.

The results of partial hypothesis testing indicate that the empathy variable $\left(\mathrm{X}_{2}\right)$ has:

1. T-count value of 18.459 is greater than the value of t-table which means that the empathy variable positively influences the level of customer satisfaction.

2. The significance value of 0,000 is smaller than $\alpha$ which means that the empathy variable significantly influences the level of customer satisfaction, where if the empathy variable is increased by one unit, the level of customer satisfaction will increase by 0.731 units.

This means that the decision is $\mathrm{Ho} 2$ rejected and $\mathrm{Ha} 2$ accepted, meaning that partially the empathy variable significantly influences the level of tourist satisfaction in South Sumatra Province.

The results of partial hypothesis testing indicate that the reciprocal variable $\left(\mathrm{X}_{3}\right)$ has:
1. T-count of 1.290 is smaller than t-table which means the reciprocal variable does not affect the level of customer satisfaction.

2. The significance value of 0.199 is greater than the $\alpha$ value which means the reciprocal variable is not significant to the level of customer satisfaction, where if the reciprocity variable is increased by one unit, the level of customer satisfaction will increase by 0.041 units.

This means that the decision is that Ho3 is rejected and Ha3 is accepted, meaning partially the reciprocal variable does not significantly influence the level of tourist satisfaction in South Sumatra Province.

The results of partial hypothesis testing indicate that the trust variable $\left(\mathrm{X}_{4}\right)$ has:

1. T-count value of 4,414 is greater than the value of t-table which means that the trust variable has a positive effect on the level of customer satisfaction.

2. The significance value of 0,000 is smaller than $\alpha$ which means that the trust variable has a significant effect on the level of customer satisfaction, where if the trust variable is increased by one unit, the level of customer satisfaction will increase by 0.151 units.

This means that the decision is Ha4 accepted and Ho4 rejected, meaning that partially the trust variable has a significant effect on the level of tourist satisfaction in South Sumatra Province.

Based on the results of partial hypothesis testing of the four independent variables which include commitment, empathy, reciprocity and trust, it is known that the commitment variable and the reciprocal variable do not have a significant effect on the level of customer satisfaction, namely tourists in South Sumatra Province, while the other two variables namely empathy and trust have a significant influence on the level of tourist satisfaction in the Selayan Sumatra Province. Of the two variables, the empathy variable has the highest level of significant influence on the level of customer satisfaction, which is also supported by 52.49 percent of respondents' positive responses. Then the trust variable is a variable that also has the second-largest level of significant influence on the level of customer satisfaction, supported by 56.32 percent positive responses.

According to Pasuraman, Zeithaml, and Berry (1991), it is suggested that customer satisfaction is the customer's feeling towards one type of service that he gets. Lovelock (2005) explains that satisfaction is an emotional state, their post-purchase reactions can be anger, dissatisfaction, irritation, excitement or pleasure. It is not surprising that each activity output has become obsessed with the level of customer satisfaction, given its direct relationship with customer loyalty, market share, and profits. Schiffman and Kanuk (2004) suggested that the level of customer satisfaction is a person's feelings toward the performance of a product or service compared to expectations. 
A basic understanding of customer satisfaction, such as the theory, implies that customer satisfaction itself has a feeling value in it. This reinforces the results of the analysis of this study which shows that the two variables in this study, namely the variables of empathy and trust variables which also have a feeling value, have a significant effect and are directly proportional to the level of customer satisfaction.

TABLE 5. TEST COEFFICIENT OF DETERMINATION Model Summary

\begin{tabular}{|r|r|r|r|l|}
\hline Model & $R$ & R Square & R Square & of the Estimate \\
\hline 1 &, $917^{2}$ &, 841 &, 838 &, 538 \\
\hline
\end{tabular}

a. Predictors: (Constant), Kepercayaan, Komitmen, Timbal_Balik, Empati

Source: Research Results, 2018 (IBM SPSS Statistics 22, processed)

Based on Table 9. shows that the R-value of 0.971 which means the influence of the four independent variables namely commitment, empathy, reciprocity and trust together on the level of customer satisfaction is very strong. While the R Square value of 0.841 means that the four independent variables influence 84.1 percent and the remaining 15.9 percent is influenced by other factors outside the research object.

\section{RESULTS}

Based on the results of research and discussion, the following conclusions are drawn:

1. From the four independent research variables, there are two dimensions, namely empathy and trust, which significantly influence the level of customer satisfaction, namely tourists in South Sumatra Province. This has been proven through the test of the significance of individual parameters and is corroborated by the results of the analysis of variable descriptions.

2. The dimensions of empathy and trust can be the initial guidelines to increase the value of the level of customer satisfaction and lead to an increase in the number of tourists in South Sumatra Province. Empathy towards tourist satisfaction is based on three indicators, namely:

a. Identification of tourist needs and desires

b. Ease of communication with the Provincial Government. South Sumatra

c. Attention and responsibility during the tour

While the level of trust by tourists can be focused on the following three indicators:

a. Professionalism in managing tourism events

b. Information on tourism products and representatives of the Provincial Government. South Sumatra

c. The consistency of tourist attraction and quality
Some policies or approaches that can be implemented in maintaining or increasing the value of customer satisfaction include:

1. Conduct a cognitive approach to tourists in understanding their needs and desires when traveling.

2. Improve the interaction and intensity of relations between the Provincial Government. South Sumatra with tourists through increasing the quantity and quality of communication media such as online social networks in particular.

3. Services when carrying out tourist activities while in Prov. South Sumatra is the main benchmark in conducting assessments. Eliminating some bureaucratic processes will improve the quality of service to tourists.

\section{REFERENCE}

[1] Berry, Leonard L. and A. Parasuraman, 1991. Marketing Services. New York: The Free Press.

[2] Chan, Syafruddin, 2003. Relationship Marketing. Jakarta: Penerbit PT. Gramedia Pustaka Umum.

[3] Christoper Lovelock, 2005. Manajemen Pemasaran Jasa, Kelompok Gramedia, Indeks, Indonesia

[4] Kotler, Philip, dan G. Amstrong, 2000. Principles of Marketing. Fifth Edition, Prentice-Hall Inc., New Jersey.

[5] Kotler, Philip, 2000. Marketing Management: The Millennium Edition. Prentice-Hall Inc., New Jersey.

[6] Kotler \& Keller, 2009. Manajemen Pemasaran. Jilid I, Edisi 13, Jakarta: Penerbit Erlangga.

[7] Little, ed dan Ebi Marandi, 2003. Relationship Marketing Management. Thomson Learning.

[8] Ngai Eric W.T., Heung Vincent C.S., Wong Y.H. dan Chan K.Y. 2007. Consumer complaint behaviour of Asians and non Asians about hotel services. European Journal of Marketing, 41(11/12): h: 1375-1391

[9] Peter, J. Paul dan Olson, Jerry, C. 2005. Cunsumer Behavior and Marketing Strategy. Sixth Edition. New York: Mc Graw Hill Companies.

[10] Rangkuti, Freddy. 2002. Measuring Customer Satisfaction: Gaining Customer Relationship Strategy. PT Gramedia Pustaka Utama, Jakarta.

[11] Schiffman \& Kanuk, 2004. Perilaku Konsumen (Edisi 7). Jakarta : Prentice Hall

[12] Simamora, Bilson, 2001. Memenangkan Pasar Dengan Pemasaran Efektif dan Profitabel,Penerbit Gramedia Pustaka Utama, Jakarta.

[13] Tandjung, J. Widodo. 2004. Marketing Management Pendekatan Pada Nilai-Nilai Pelanggan. Malang: Bayumedia Publishing

[14] Tjiptono, Fandy. 2005. Strategi Pemasaran. Edisi Kedua. Cetakan Keenam. Yogyakarta: Penerbit. Andy.

[15] Tjiptono, Fandy, 2006. Pemasaran Jasa. Edisi Pertama, Cetakan Kedua, Penerbit Bayumedia Publishing, Malang.

[16] Tjiptono, Lupiyoadi Rahmat, Hamdani A, 2006. Manajemen Pemasaran Jasa, Edisi Kedua, Penerbit Salemba Empat, Jakarta.

[17] Yau, Oliver H.M., et al. 1999. Is Relationship for Every One". European Journal of Marketing. Vol. 43, Page 4-10.

[18]Zeithaml dan Bitner, 2003. Service Marketing. Jakarta: Penerbit Erlangga. 